\title{
29
}

\section{Clogging of Permeable Concrete Block Pavement by Street Particulates and Rain}

\author{
William James
}

Clogging of permeable interlocking concrete block pavement (PP) was studied. Samples of parking lot dust and dirt (D\&D) were collected from an existing PP installation and processed to remove moisture and volatile compounds. The samples were analyzed for their particle size distribution. For the experiments, city street D\&D was then collected in larger quantities, processed and reconstituted into the same fractions found on the permeable paver surface.

Tests were then conducted on a full-scale PP set up in a special outdoor rig. Synthesized D\&D and artificial, intense rains were systematically applied to the pavement, and surface and subsurface drainage flow rates measured. Four different PPs were tested and drainage cell, bedding and base material throughout the test pavement analyzed.

Results indicated the rate at which the synthesized D\&D may clog the drainage cells of PP.

\subsection{Introduction}

Permeable interlocking concrete block pavement $(\mathrm{PP})$ is one of many structural best management practices (BMPs) designed to mitigate the impacts of increased volumes of runoff and of increased production and export of

James, W. 2004. "Clogging of Permeable Concrete Block Pavement by Street Particulates and Rain." Journal of Water Management Modeling R220-29. doi: 10.14796/JWMM.R220-29.

(C) CHI 2004 www.chijournal.org ISSN: 2292-6062 (Formerly in Innovative Modeling of Urban Water Systems. ISBN: 0-9683681-9-0) 
pollutants from urban catchments. PP reduces runoff volumes by permitting water to infiltrate through open drainage cells in the paver surface to the underlying stormwater reservoir. This form of treatment is known as source control (Pratt, 1995).

Pavers comprising modular interlocking concrete blocks with external drainage cells (MICBECs) are designed to provide a durable surface, high infiltration rate and drainage cell material that is relatively easily maintained by sweeping, pressure-washing and vacuuming (Kresin et al., 1996). In this study we used the MICBECs illustrated in Figures 29.1 and 29.4. The volume of aggregate in the base, below the bedded permeable pavers, is typically sized to attenuate a moderate rainfall event, which can range from 10 to $25 \mathrm{~mm}(0.5$ to 1.5 in.) but may be much larger. Drainage of the base reservoir is designed to evacuate stored water before the next rain event, typically within $24 \mathrm{~h}$.

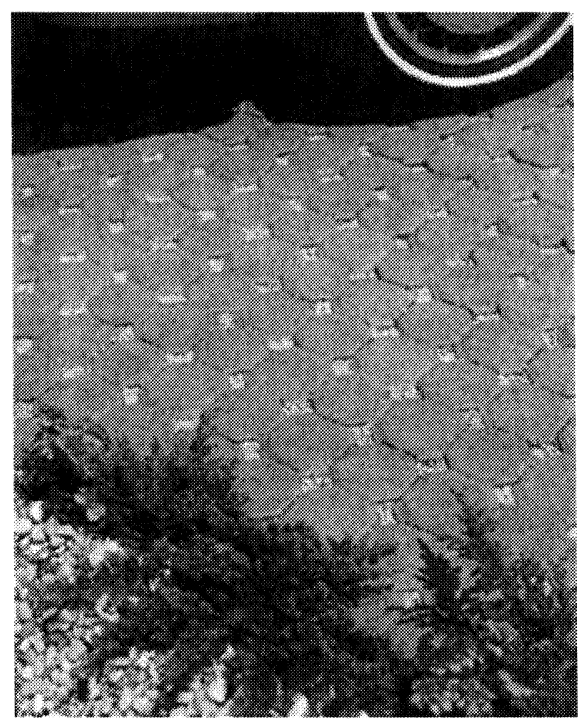

Figure 29.1 A MICBEC paver. Chamfers on the cell inlet and grooves on the paver surface channel rain water into the open cells; cell material is maintained below the lower edge of the entry chamfer to avoid compressing the cell material by tires.

One of the primary concerns with PP is clogging with fine-grained particles (Schueler, 1987). Performance with respect to clogging varies widely depending on many parameters, and the issue is complicated by the fact that methodologies for determining the design parameters have not been developed (Mikkelsen et al., 1996). 


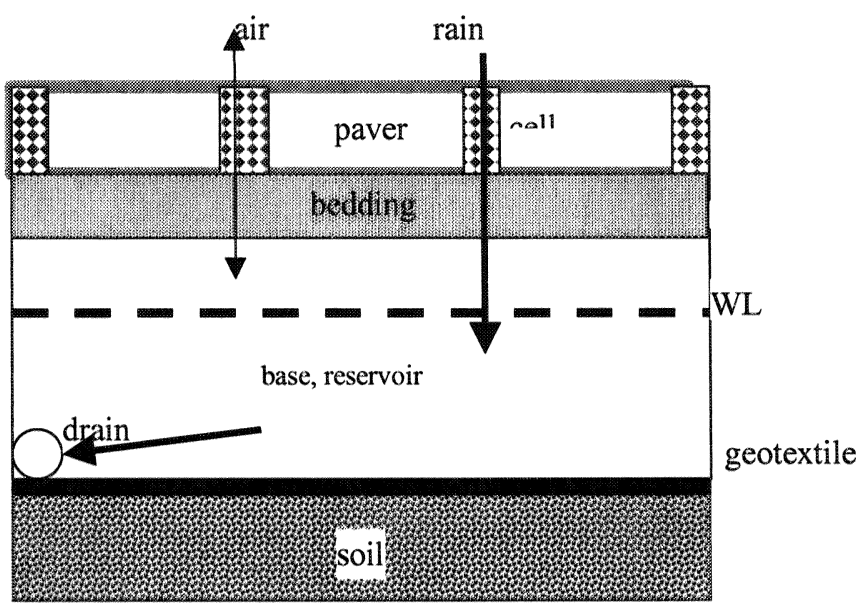

Figure 29.2 Vertical section showing components of a permeable pavement (geotextile and drain are optional; drainage cells may penetrate the bedding layer; $\mathrm{WL}=$ transient water level).

Our general objective was to investigate changes in the permeability of the PPs resulting from the artificial application of sediment and rainfall to the paver surface. Effects of traffic and natural weather conditions were deliberately excluded in this study. Changes in permeability were assessed experimentally to determine the approximate number and quantity of sediment-rain events that may cause clogging of the pores in the drainage cell in the absence of traffic. Clogging is defined by changes in the hydrologic response of the pavers.

In point form, the particular objectives were to:

- design and build a suitable experimental apparatus,

- determine the natural rate of accumulation of sediment (dust and dirt, D\&D) collecting on the University of Guelph PP parking lot,

- remove moisture and volatile organic matter from the D\&D appropriately in ovens, and conduct a particle size distribution analysis on the remaining material (denoted total suspended solids,TSS herein) and synthesize a large quantity of TSS with the same particle size distribution, from the City of Guelph street $\mathrm{D} \& \mathrm{D}$, for use in the study,

- determine an appropriate rainfall (intensity, duration) for this experiment and construct a suitable rain simulator, and

- apply sediment-rain events and determine the rate of clogging, by measuring the increase in surface runoff and decrease in base drainage. 


\subsection{Background Review}

\subsubsection{Introduction}

On urban surfaces, vehicular traffic and other urban activities impose pollutants that are transported by surface runoff to the nearest water bodies (Lawrence et al., 1996). Many studies have demonstrated that PP significantly reduces the volume of stormwater and associated pollutant loads (Balades et al., 1995; Pratt et al., 1995; St. John and Horner, 1997a\&b; Strecker et al., 2001). As shown in Table 29.1, infiltration through PP provides cool, filtered water with reductions in fine-grained sediments, nutrients, organic matter, and trace metals (Schueler, 1987).

In 1990 the U.S. Environmental Protection Agency (EPA) established an $80 \%$ standard for removal of TSS from urban runoff for new developments, roads, highways and bridges and storms less than or equal to the 2-y, 24-h storm (EPA, 2002). Schueler and Brown (1997) summarized 123 research studies on the performance of various urban drainage BMPs. As indicated in Table 29.1, PP can be particularly effective for removing suspended sediments and sediment-bound pollutants from runoff. Removal mechanisms associated with infiltration include settling, filtration, adsorption, ion exchange, and biological decomposition (St. John and Horner, 1997a\&b). By removing finegrained sediments and sediment-bound pollutants, PPs facilitate compliance with stormwater regulatory requirements. Table 29.2 presents the initial and, where available, the long-term, in-situ infiltration rates for a variety of PP installations.

Schueler (1987) specifically cautioned against building PP systems where they are expected to receive particulates such as those associated with road sanding. In most major cities in Ontario, road-sanding operations are routinely performed during periods of snow and ice. In Table 29.3, St. John and Horner (1997a\&b) present the long-term in-situ infiltration rates for PP, from experiments on the effect of road sanding operations.

As reported in Tables 29.2 and 29.3, infiltration rates associated with PP generally decrease with time. The cause is clogging of the pavement pores with fine sediment. Studies in France and the Netherlands suggest that one third of the permeability of PP can be lost in the first year due to clogging (Lefebvre, 1993). Proper adherence to site selection criteria, construction and maintenance schedules are essential to realizing the potential life expectancy of PP. Violations of these criteria have led to as much as $75 \%$ of PP systems surveyed in Maryland to be totally or partially clogged within 5 y (Young et al., 1996). 
Table 29.1 Pollutant removal by permeable pavements.

\begin{tabular}{cccccc}
\hline & \multicolumn{5}{c}{ Pollutant Removal (\%) } \\
\hline Study & TSS $^{1}$ & TP $^{2}$ & TN $^{3}$ & COD $^{4}$ & Metals \\
\hline Prince William, VA & 82 & 65 & 80 & - & - \\
Rockville, MD & 95 & 65 & 85 & 82 & $98-99$ \\
\hline
\end{tabular}

(1) Total Suspended Sediments, (2) Total Phosphorus, (3) Total Nitrogen, (4) Chemical Oxygen Demand. (Schueler, 1987)

Table 29.2 In-situ infiltration rates for a variety of permeable paver installations.

\begin{tabular}{ccc}
\hline Installation Description & Initial Infiltration & $\begin{array}{c}\text { Long-Term Infiltration } \\
\text { Time elapsed, rate }\end{array}$ \\
\hline $\begin{array}{c}\text { PP system in parking lots in } \\
\text { Austin, Texas }\end{array}$ & $4,485 \mathrm{~mm} / \mathrm{h}$ & None reported \\
PP section on Arizona & $(1,765 \mathrm{in} . / \mathrm{h})$ & After $4 \mathrm{y}$, \\
highway & $1,960 \mathrm{~mm} / \mathrm{h}$ & $1,020 \mathrm{~mm} / \mathrm{h}$ \\
& $(77 \mathrm{in} . / \mathrm{h})$ & $(40 \mathrm{in} . / \mathrm{h})$ \\
17 permeable asphalt test & $8,510 \mathrm{~mm} / \mathrm{h}$ & After $4 \mathrm{y}$ \\
sections on motorways, & $(335 \mathrm{in} . / \mathrm{h})$ & $5,335 \mathrm{~mm} / \mathrm{h}$ \\
interurban, and urban roads ${ }^{3}$ & & $(210 \mathrm{in} . / \mathrm{h})$ \\
Concrete block permeable & After $9 \mathrm{y}$ \\
pavers in a parking lot ${ }^{4}$ & None reported & $990 \mathrm{~mm} / \mathrm{h}$ \\
& & $(39 \mathrm{in} . / \mathrm{h})$ \\
Permeable pavers surfacing & $46,700 \mathrm{~mm} / \mathrm{h}$ & After $4 \mathrm{y}$ \\
of roadways in residential & $(1,840 \mathrm{in} . / \mathrm{h})$ & $21,600 \mathrm{~mm} / \mathrm{h}$ \\
and industrial areas & & $(850 \mathrm{in} . / \mathrm{h})$ \\
\hline
\end{tabular}

${ }^{1}$ Goforth et al., $1983 ;{ }^{2}$ Hossain and Scofield, $1991 ;{ }^{3}$ Isenring et al., 1990; ${ }^{4}$ Pratt et al., 1995;

${ }^{5}$ Balades et al., 1995

Table 29.3 Average in-situ infiltration rates of permeable asphalt shoulder over time (St. John and Horner, 1997a\&b).

\begin{tabular}{cc}
\hline Time Since Construction (months) & $\begin{array}{c}\text { Mean Infiltration } \\
{[1 \mathrm{std} . \text { Deviation }]}\end{array}$ \\
\hline 11 (following implementation) & $44,500[4,500] \mathrm{mm} / \mathrm{h}(1,750[177]) \mathrm{in} . / \mathrm{h}$ \\
20 (prior to sanding experiment) & $1,450[3,560] \mathrm{mm} / \mathrm{h}(57[140]) \mathrm{in} / \mathrm{h}$ \\
48 (following sanding experiment) & $36[100] \mathrm{mm} / \mathrm{h}(1.4[4.1]) \mathrm{in} . / \mathrm{h}$ \\
\hline
\end{tabular}




\subsubsection{Maintenance Considerations}

The effectiveness and sustainability of any management practice designed for the mitigation of stormwater impacts has to be ensured by proper operation and maintenance (Ellis and Marsalek, 1996). PP systems are no different and require maintenance to retain permeability (e.g., Goforth et al., 1983; Hossain and Scofield, 1991; Mikkelsen et al., 1996). Typical requirements are shown in Table 29.4.

Since PP is an effective trap for solids, the portion of solids trapped at the surface can be cleaned off the surface as a part of routine maintenance. The most effective cleaning method is the use of a vacuum street sweeper followed by a high-pressure wash (Young et al., 1996). Proper treatment of the removed material, such as transport to a landfill site, will prevent cross contamination.

Table 29.4 Typical maintenance activities for permeable pavers ( WMI, 1997).

\begin{tabular}{lc}
\multicolumn{1}{c}{ Activity } & Schedule \\
\hline Avoid sealing or repaving with non-permeable materials. & N/A \\
Ensure that paving area is clean of debris. & Monthly \\
Ensure that paving dewaters between storms. & \\
Ensure that the area is clean of sediments. & As needed \\
Mow upland and adjacent areas, and seed bare areas. & $\begin{array}{c}\text { Annuly } \\
\text { Vacuum or sweep frequently to keep the surface sediment } 3-4 / y)\end{array}$ \\
free. & Annual \\
Inspect the surface for deterioration or spalling. &
\end{tabular}

\subsection{Experimental Apparatus}

\subsubsection{Introduction}

Our experiments were performed outdoors in the parking lot at the School of Engineering at the University of Guelph during summer 2002, which was generally dry and warm. A rig was constructed with a surface area of $0.93 \mathrm{~m}^{2}$ $(0.615 \mathrm{~m}$ by $1.51 \mathrm{~m}, 2.25 \mathrm{ft}$ by $5 \mathrm{ft})$, incorporating an otherwise full-scale Ecostone pavement at a slope of $2 \%$. The experimental apparatus is illustrated conceptually in Figure 29.3. The frame was constructed of mild steel, providing adequate strength for supporting the relatively heavy concrete pavers and the pavement base. For visual monitoring of surface runoff and percolation in the underlying sub-base, the sidewalls of the flume were constructed of Plexiglas. 


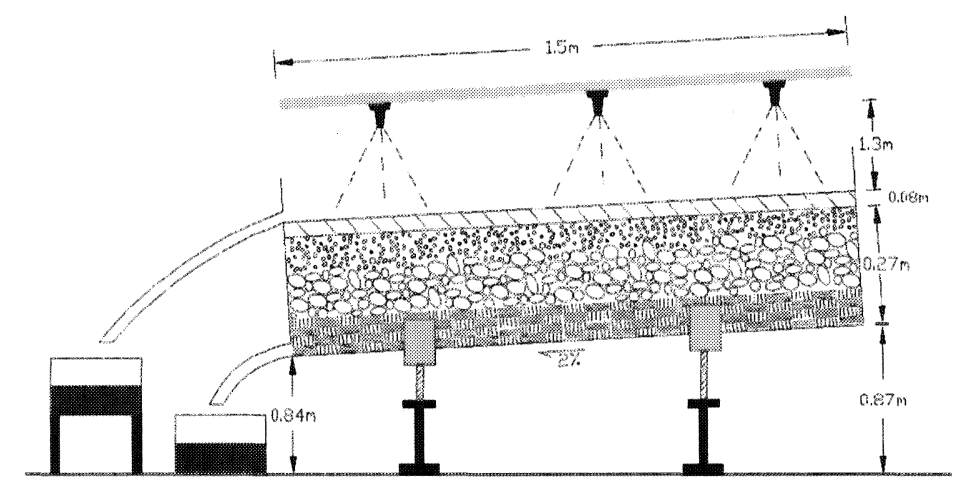

Figure 29.3 Permeable paver schematic - in the experiment only two rain nozzles were used.

Artificial rain was generated using a rainfall simulator having two $12 \mathrm{~mm}(0.5$ in.) diameter nozzles, supplied by a submersible pump operating at $0.7-0.85 \mathrm{bar}$ (10 to $12 \mathrm{psi}$ ) (Wilson, 2002). In real pavements, the base may be laid over subgrade, but in these experiments the $200 \mathrm{~mm}$ ( $8 \mathrm{in}$.) base layer of aggregate was laid over the impervious steel invert of the rig, drained at the downstream edge by three $12 \mathrm{~mm}(0.5 \mathrm{in}$.) diameter pipes.

At the lower edge of the aggregate base, a $100 \mathrm{~mm}$ (4 in.) perforated pipe covered with geotextile filter fabric was placed across the base, covering the three $12 \mathrm{~mm}(0.5 \mathrm{in}$.) pipes that drained to an external container. Each pipe was attached to a hose from which the base drainage was sampled. Surface runoff rate was sampled from the inclined overflow that was adjusted to the height of the paver surface. Polythene sheeting curtained the rig to ensure uniformity of simulated rain and prevent splash into the sampling area.

\subsubsection{Rainfall}

The rainfall simulator comprised a submersible pump, hoses and pipes, a globe valve, gate valve, a pressure gauge and two $12 \mathrm{~mm}(0.5 \mathrm{in}$.) rainfall-simulating nozzles positioned to provide uniform coverage of the paver surface.

Many surface drainage systems are designed to handle a $2 y$ frequency rainfall event, and Ecostone pavement is generally designed to accommodate the $1 \mathrm{~h} / 1 \mathrm{y}$ or $1 \mathrm{~h} / 2 \mathrm{y}$ frequency storm, corresponding to an expected rainfall intensity of $23 \mathrm{~mm} / \mathrm{h}$ (Uni-Group U.S.A., 2001; Environment Canada, 2002). 
In this experiment the artificial rain on the paver surface was arbitrarily set to a maximum rate likely to be experienced over of short duration of an intense rainfall. To test clogging of the pavement, many cycles of rainfall and sediment application were required. Due to time considerations a short rainfall duration of $5 \mathrm{~min}$ was used. The resulting 5 -min rainfall with an intensity of between 200 and $230 \mathrm{~mm} / \mathrm{h}$ corresponds to a $25 \mathrm{y}$ frequency storm, on the IntensityDuration Frequency Curve for Toronto (Environment Canada, 2002). The rainfall was sampled as indicated in Figure 29.4.

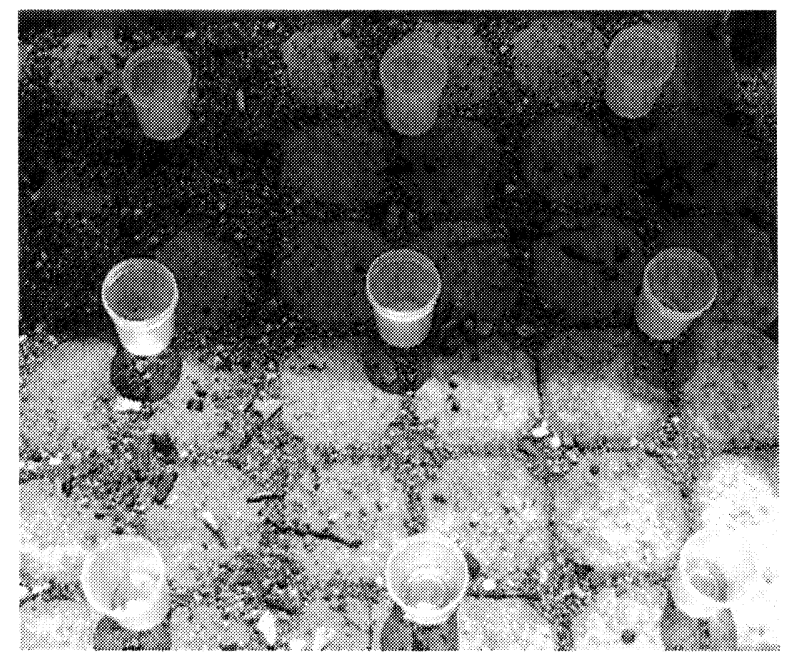

Figure 29.4 Rain sampling on part of the paver surface, showing the surface condition after application of ca. $3 \mathrm{~kg} / \mathrm{m}^{2} \mathrm{TSS}$.

\subsubsection{Surface Infiltration}

Surface infiltration through permeable pavement is largely dependent on the area and depth of the drainage cell and on the hydraulic conductivity of the specific mix of fill materials used in the drainage cell. Other characteristics of the cell fill material that affect the infiltration rate include the air and water content of the cell fill (Evans, 1989). The infiltration rate is the speed (length/ time) at which water flows downward through the drainage cell and is a result of the combined forces acting on the water molecules. These forces are gravity acting downward, negative pore water pressure, drag forces on the aggregate 
acting against the flow, and the forces associated with passage of air upwards escaping the base aggregate, also opposing the flow. Negative pore water pressure is also known as soil water suction, tension, capillary pressure and matric potential.

\subsubsection{Saturated Hydraulic Conductivity of the Base and Drainage Cell Material}

Subsurface drainage removes water that has infiltrated into the base through the surface. The rate that this water moves through the base depends on the hydraulic conductivity (permeability), slope and thickness of the respective layers, as well as the hydraulics of any drainage pipes provided.

A particle size distribution was performed on the high performance aggregate used as base and fill material, and the results were found to be compatible with those of Cedergren et al. (1973).

To determine the porosity and saturated hydraulic conductivity of the base and drainage cell fill material, water was added to the pavement surface until the base and drainage cell fill was completely saturated with water (the point that water was visible at the pavers surface). The water was then permitted to drain. The change in water height in the container was recorded at 1-min intervals until all the water had drained from the apparatus.

The saturated hydraulic conductivity was taken to be the rate of the draining water over the first $15 \mathrm{~s}$, estimated from our measurements to be approximately $1,430 \mathrm{~mm} / \mathrm{h}$, notwithstanding problems of air entrainment and movement.

\subsubsection{Porosity of the Base and Drainage Cell Fill Material}

Porosity is the ratio of the volume of voids (soil pores) to total volume of a unit of soil. Similarly, moisture content $\theta$ is the ratio of a volume of water, to the total volume of a unit of soil. When the soil is saturated all the soil pores are full of water and the soil moisture becomes equal to the porosity of the soil sample. The pavement base was filled with water and allowed to stand for some days. No attempt was made to artificially eliminate air from the voids. The total amount of water that drained from the saturated pores into the container was measured and used to calculate the total porosity (pore space ratio), and the maximum was found to be $0.34 \mathrm{~m}^{3} / \mathrm{m}^{3}$ or $34 \%$. 


\subsection{Synthesis and Application of Street D\&D}

\subsubsection{Introduction}

The mechanisms of buildup of street D\&D involve factors such as wind, traffic, atmospheric fallout, land surface activities, erosion, street cleaning and other imponderables (James et al., 2003). D\&D was collected over a 2-week period in the spring of 2002, from the permeable paver test section of the University of Guelph parking lot using a high-pressure vacuum. Table 29.5 provides the observed loading of sediment per unit area $\left(\mathrm{kg} / \mathrm{m}^{2}\right)$ over three zones: the low traffic area closest to the curb, the medium traffic area, and the high traffic area furthest from the curb. The average loading value over all three zones is $0.11 \mathrm{~kg} / \mathrm{m}^{2}\left(0.023 \mathrm{lbs} / \mathrm{ft}^{2}\right)$. The highest loading occurred in the low traffic zone resulting from the accumulation of organic matter, predominantly pine needles near the curb. Although a build-up period of 1 dry day was thought to have occurred, based on the frequency of vacuuming, it is by no means clear that the assumption was reasonable, because of the limited dataset.

Table 29.5 Initial D\&D buildup data for permeable pavement.

\begin{tabular}{cccccc}
\hline $\begin{array}{c}\text { Traffic } \\
\text { zone }\end{array}$ & Date & Time & $\begin{array}{c}\text { Dry Wt } \\
(\mathrm{kg})\end{array}$ & $\begin{array}{c}\text { Area Sampled } \\
\left(\mathrm{m}^{2}\right)\end{array}$ & $\begin{array}{c}\text { Loading } \\
\mathrm{kg}\end{array}$ \\
\hline High & $5 / 9 / 02$ & $17: 00$ & 6.116 & 62.608 & 0.0977 \\
Medium & $5 / 9 / 02$ & $19: 00$ & 6.512 & 72.800 & 0.0895 \\
Low & $5 / 9 / 02$ & $20: 30$ & 3.762 & 25.48 & 0.1476 \\
\hline
\end{tabular}

(Weather at date of collection: High: 15 Low: 4. Precip: P.O.P. $20 \%$, Amount: 0 mm; Wind: $20 \mathrm{~km} / \mathrm{h} \mathrm{SW}$ ), assuming a build-up period of 1 dry day.

Table 29.6 Buildup data from the second collection.

\begin{tabular}{cccccc}
\hline $\begin{array}{c}\text { Zone } \\
\text { Collected }\end{array}$ & Date & $\begin{array}{c}\text { Time of } \\
\text { Day }\end{array}$ & $\begin{array}{c}\text { Dry Weight } \\
(\mathrm{kg})\end{array}$ & $\begin{array}{c}\text { Area Sampled } \\
\left(\mathrm{m}^{2}\right)\end{array}$ & $\begin{array}{c}\text { Loading } \\
\mathrm{kg}\end{array}$ \\
\hline High Traffic & $5 / 15 / 02$ & $13: 00$ & 5.595 & 62.608 & 0.0894 \\
$\begin{array}{c}\text { Medium } \\
\text { Traffic }\end{array}$ & $5 / 15 / 02$ & $14: 30$ & 3.696 & 72.800 & 0.0508 \\
Low Traffic & $5 / 15 / 02$ & $16: 30$ & 1.601 & 25.48 & 0.0628 \\
\hline
\end{tabular}

(Buildup: None; Washoff: One day after $4 \mathrm{~d}$ of rain. Weather at collection date: High 18, Low: 7; Precip. P.O.P. $0 \%$ Amount: $0 \mathrm{~mm}$; Wind: $25 \mathrm{~km} / \mathrm{h} \mathrm{W}$ ) 
The second collection was taken six days later from the same paver area following 4 days of near continuous rain. The loading was considerably lower than the initial collection, as shown in Table 29.6. The averaged loading value over all three zones for the second collection is $0.068 \mathrm{~kg} / \mathrm{m}^{2}\left(0.014 \mathrm{lb} / \mathrm{ft}^{2}\right)$, and the low traffic zone did not have the highest loading, which was observed in the high traffic zone. The results indicate that the build-up rate is very uncertain, perhaps in the range 0.01 to $0.1 \mathrm{~kg} \mathrm{~m}^{-2}$-dryday-1.

\subsubsection{Recommended Sediment Application Rates}

For these admittedly very sparse observation periods, the loading at the University of Guelph permeable pavers parking lot indicated a maximum accumulation of street $\mathrm{D} \& \mathrm{D}$ of $0.1 \mathrm{~kg} / \mathrm{m}^{2}\left(0.02 \mathrm{lbs} / \mathrm{ft}^{2}\right)$. To manage the experiments within the two-month timeframe allowed by the available research budget, the maximum loading rate was used in conjunction with very high applied rain rates.

\subsubsection{Particle Size Distribution for the Initial Collection}

Three samples of D\&D, one each from the three traffic zones, were taken from the initial collection for an analysis of the particle size distribution. Each sample was heated in a precision oven at $103^{\circ} \mathrm{C}$ for $24 \mathrm{~h}$. After heating, the samples were weighed again to determine the loss in weight due to evaporation from the soil sample. The results showed moisture contents of $0.3 \%$ to $10.3 \%$.

The near curb zone had the highest amount of moisture, and conversely the high traffic zone had least. The dried samples were subjected to further heat to remove volatile organics and then sieved using U.S. standard sieve sizes and a mechanical sieve shaker, and the results are presented graphically in Figure 29.5.

\subsubsection{Sieve Analysis}

The bulk of the three samples comprise coarse to medium sand. The quantity of the sample that is larger than $4.75 \mathrm{~mm}$ is highest for the near curb zone and decreases substantially out from the curb to the high traffic area. The portion of the sample finer than US standard sieve sizes \#200 is highest in all cases for the high traffic area. 


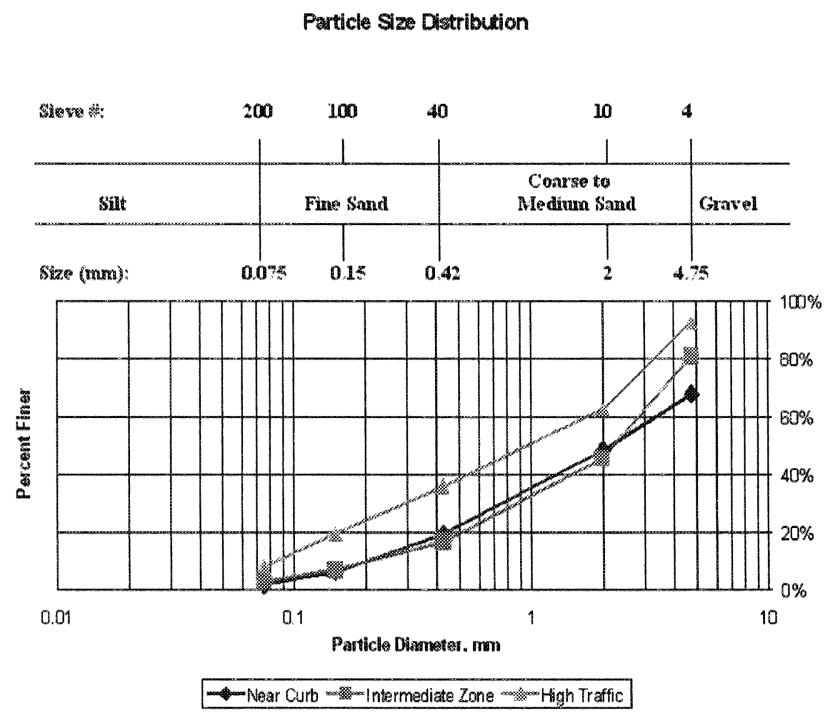

Figure 29.5 Particle size distributions for three traffic zones.

\subsubsection{Synthesis of Parking Lot D\&D from Street D\&D}

A large quantity of D\&D, collected from City of Guelph street sweepers, was heated in an oven and then separated into silt, fine sand, medium sand, coarse sand and gravel by sieving. These separated sediments were then remixed in the same proportions found in the material collected from the University of Guelph permeable parking lot. The particle size distributions reported for the three traffic zones had been previously averaged to produce one representative particle size distribution.

\subsection{The Experiments}

The study comprised four experiments, each experiment having a specific base, bedding and fill aggregate. By fill aggregate we mean the aggregate placed in the open drainage cells. By experiment we mean that a specific paver structure is placed in the rig for a sequence of runs. Each application of TSS and rain is called a run. Each run was subject to TSS applied at a fixed rate, followed by a specified intensity $(230 \mathrm{~mm} / \mathrm{h}, 9 \mathrm{in} . / \mathrm{h})$ of artificial rain applied for a duration 
of $305 \mathrm{~s}$ (just over $5 \mathrm{~min}$ ). In other words, each run, within an experiment, comprised one uniformly distributed load of TSS followed by one uniformly distributed rain. Flow (surface runoff and drain-flow) was measured over a sample duration of $20 \mathrm{~s}$ twice a minute for the first $6 \mathrm{~min}$, and thereafter once a minute until a minimum flow rate was reached. A sample was taken from $280 \mathrm{~s}$ to $300 \mathrm{~s}$ after the start of rain and the pump was stopped after securing the collected sample, thus necessitating the extra $5 \mathrm{~s}$ beyond $300 \mathrm{~s}$. Graduated containers were used to measure the flow volume, at an estimated uncertainty of $5 \%$.

In our experiments, TSS was manually spread uniformly over the paver surface at the beginning of each run before applying rain. The gradation was not varied in this entire series of experiments. Sufficient TSS was synthesized to the particle size distribution given in Table 29.7. Error was estimated to be $5 \%$ for particles sizes exceeding $2 \mathrm{~mm}$ and $1 \%$ for the remaining particle sizes.

Table 29.7 Gradation of TSS applied to the surface.

\begin{tabular}{lll}
\hline Sieve \# & \multicolumn{1}{c}{$\begin{array}{c}\text { Diameter } \\
(\mathrm{mm})\end{array}$} & $\begin{array}{c}\text { TSS applied } \\
(\mathrm{gm})\end{array}$ \\
\hline$\# 4$ & 4.75 & 19.62 \\
$\# 10$ & 2.00 & 28.29 \\
$\# 40$ & 0.425 & 27.95 \\
$\# 100$ & 0.15 & 13.42 \\
$\# 200$ & 0.075 & 6.63 \\
Pan & $<0.075$ & 4.03 \\
Total & & 99.93 \\
\hline
\end{tabular}

At the end of each experiment, fill aggregates and base aggregates were analyzed to determine the TSS trapped. For this purpose the paver surface was cleaned and fill aggregate carefully removed for each $5 \mathrm{~mm}$ depth from each drainage cell of the paver. Samples were separately collected to a total depth of $40 \mathrm{~mm}$, at which point base aggregate was reached. The blocks were removed and four samples were collected from the base aggregate at depths of $0-80 \mathrm{~mm}$, 81-160 mm, 161-250 $\mathrm{mm}$ and one sample was also taken of the aggregate immediately under the blocks. All samples were oven dried and analyzed for particle size distribution. Results for base aggregate showed no change from their original particle size distribution.

For all four experiments, the TSS applications rates, and rainfall intensities are summarized in Tables 29.8 and 29.9. Results from experiment 1 are not discussed here, because of data processing problems. 
Table 29.8 Aggregate and sediment conditions for the 4 experiments.

\begin{tabular}{|c|c|c|c|c|c|c|c|}
\hline \multirow[t]{3}{*}{$\#$} & \multicolumn{6}{|c|}{ Paver Structure } & \multirow{3}{*}{$\begin{array}{l}\text { TSS } \\
\mathrm{g} / \mathrm{m}^{2}\end{array}$} \\
\hline & \multicolumn{2}{|c|}{ Base } & \multicolumn{2}{|c|}{ Bedding } & \multicolumn{2}{|c|}{ Fill } & \\
\hline & Aggregate & $\begin{array}{c}\text { Depth } \\
\mathrm{mm}\end{array}$ & Aggregate & $\begin{array}{c}\text { Depth } \\
\text { mm }\end{array}$ & Aggregate & $\begin{array}{c}\text { Depth } \\
\mathrm{mm}\end{array}$ & \\
\hline 1 & $\begin{array}{l}\text { Aerofoil- } \\
\text { HPB }^{*}\end{array}$ & 250 & - & 0 & $\begin{array}{c}\text { Aerofoil- } \\
\text { HPB }\end{array}$ & 40 & 100 \\
\hline 2 & $\begin{array}{c}\text { Aerofoil- } \\
\text { HPB }^{*}\end{array}$ & 250 & - & 0 & $\begin{array}{l}1: 1 \text { by Vol. } \\
\text { Sand:HPB }\end{array}$ & 40 & 100 \\
\hline 3 & $\begin{array}{c}\text { Milton } \\
\text { Granular-A* }\end{array}$ & 200 & $\begin{array}{l}\text { Aerofoil- } \\
\text { HPB }^{*}\end{array}$ & 5 & $\begin{array}{l}1: 3 \text { by Vol } \\
\text { Sand:HPB }\end{array}$ & 40 & 100 \\
\hline 4 & $\begin{array}{c}\text { Milton } \\
\text { Granular-A* }\end{array}$ & 200 & $\begin{array}{c}\text { Aberfoyle } \\
\text {-HPB }\end{array}$ & 5 & $\begin{array}{l}1: 1 \text { by Vol. } \\
\text { Sand:HPB }\end{array}$ & 40 & 25 \\
\hline
\end{tabular}

* For details refer to Dufferin Aggregates, Concord, Ontario.

Table 29.9 Applied rain for the 4 experiments.

\begin{tabular}{lll}
\hline$\#$ & \multicolumn{1}{c}{$\begin{array}{c}\text { Intensity } \\
\text { mm-h }^{-1}\end{array}$} & $\begin{array}{c}\text { Duration } \\
\text { s }\end{array}$ \\
\hline 1 & 230 & 300 \\
2 & 277 & 305 \\
3 & $277-200$ & 305 \\
4 & 200 & 305 \\
\hline
\end{tabular}

\section{Experiment 2}

Summarized in Table 29.10 are peak drain flows over 34 runs with a cumulative total TSS application of $3.4 \mathrm{~kg} / \mathrm{m}^{2}$. Generally peak drain flow occurred $6.33 \mathrm{~min}$ after the start of rain and lasted $15 \mathrm{~min}$.

Table 29.10 Experiment 2: Summary of peak drain flow.

\begin{tabular}{lcc}
\hline Run & $\begin{array}{c}\text { Total TSS } \\
\mathrm{g} / \mathrm{m}^{2}\end{array}$ & $\begin{array}{c}\text { Peak flow } \\
\mathrm{mm} / \mathrm{h}\end{array}$ \\
\hline R2 & 200 & 80 \\
R4 & 400 & 40 \\
R17 & 1,700 & 24 \\
R22 & 2,200 & 19 \\
R28 & 2,800 & 17 \\
R34 & 3,400 & 17 \\
\hline
\end{tabular}


It was concluded that very little TSS is trapped in the high performance base (HPB). Furthermore, at the end of experiment 2, and after the removal of all the base aggregate, a small quantity of fines were found at the base of the rig at the drain filter fabric. This suggests that some fine particles pass through the fill aggregate, the HPB-base, and accumulate on the drain filter fabric.

Results of fill aggregate analysis however suggest that most fines were trapped in the top-most layer of fill aggregate while the lowest layer (at $40 \mathrm{~mm}$ depth) trapped almost no fines. Trapping of fines evidently decreases with depth.

\section{Experiment 3}

For experiment 3, the $200 \mathrm{~mm}$ layer of base aggregate was Milton Granular-A from Dufferin Aggregate. The bedding layer consisted of Aberfoyle HPB aggregate also supplied by Dufferin Aggregate. Drainage cells were filled with a filler aggregate consisting of 33\% Class-C sand and $67 \%$ Aberfoyle-HPB by volume. Laboratory analysis of base aggregate, bedding HPB and fill aggregate was performed.

A total of $7.1 \mathrm{~kg} / \mathrm{m}^{2}$ of TSS was applied. Experiment 3 differed from Experiment 2 in two main respects: (i) base aggregate contained more fine particles and (ii) fill aggregate contained more coarse aggregate. The Milton Granular-A base aggregate remained saturated over a longer period.

Peak drain flow over the 83 runs with a total TSS application of $6.8 \mathrm{~kg} / \mathrm{m}^{2}$ is summarized in Table 29.11 .

Table 29.11 Experiment 3: Summary of peak flow during wet runs.

\begin{tabular}{lcc}
\hline Run & $\begin{array}{c}\text { Total TSS } \\
\text { gm }\end{array}$ & $\begin{array}{c}\text { Peak flow } \\
\mathrm{mm} / \mathrm{h}\end{array}$ \\
\hline R1 & 0 & 195 \\
R15 & 1,000 & 127 \\
R34 & 2,700 & 120 \\
R37 & 2,900 & 97 \\
R50 & 3,800 & 89 \\
R63 & 4,900 & 55 \\
R75 & 6,000 & 60 \\
\hline
\end{tabular}

The first run each day was assumed to be a dry run, where initial moisture conditions were thought to be constant. Dry run comparisons are judged to give better results, as shown in Table 29.12. This comparison shows that run 51 (with a total TSS application of $3.8 \mathrm{~kg} / \mathrm{m}^{2}$ ) showed a reduced peak drain flow 
Table 29.12 Experiment 3: Summary of peak flows during dry runs.

\begin{tabular}{lrc}
\hline Run & $\begin{array}{c}\text { Total TSS } \\
\text { gm }\end{array}$ & $\begin{array}{c}\text { Drain flow } \\
\mathrm{mm} / \mathrm{h}\end{array}$ \\
\hline R3 & 0 & 156 \\
R10 & 500 & 108 \\
R36 & 2,800 & 88 \\
R51 & 3,800 & 68 \\
R62 & 4,800 & 35 \\
R74 & 5,900 & 54 \\
\hline
\end{tabular}

of $68 \mathrm{~mm} \cdot \mathrm{h}^{-1}$ and run $74\left(5.9 \mathrm{~g} / \mathrm{m}^{2}\right.$ of TSS ) shows minor further decrease, relative to the TSS applied. Run 62 produced a peak drain flow of $35 \mathrm{~mm} / \mathrm{h}$, which is less than the subsequent dry run. The main reason for this change was that run 62 occurred after a four day break when the base was drier, compared to other dry runs and thus produced lower drain flow (compared even to subsequent days' first run). This confirms that the base used in experiment 3 holds moisture for a longer time.

Samples analyzed showed that most of the fines were trapped within 10 $\mathrm{mm}$ of the top layer of the fill aggregate, while some fines also accumulated down to the $40 \mathrm{~mm}$ depth, at the bottom of the fill aggregate.

\section{Experiment 4}

The main purpose of this experiment was to study paver performance at a lower TSS build up rate.

Base aggregate was Aberfoyle high performance base (HPB). Drainage cells were filled with a filler aggregate consisting of $50 \%$ by volume of Class$\mathrm{C}$ sand and 50\% HPB. The particle size distribution of the fill aggregate was also analyzed.

An average rainfall of $200 \mathrm{~mm} \cdot \mathrm{h}^{-1}$ was applied at a uniformity coefficient of $78 \%$, a measure of the distribution of rain sampled on the paver surface. TSS was applied at a uniform rate of $25 \mathrm{~g} / \mathrm{m}^{2}, 25 \%$ of the rate used in previous experiments. The rainfall intensity during this experiment was reduced from 277 to $200 \mathrm{~mm} \cdot \mathrm{h}^{-1}$, to examine the effect of this variation.

Experiment 4 was run 133 times with a total TSS application of $3,225 \mathrm{~g} / \mathrm{m}^{2}$. Based on previous experimental observations, each day's first run (the dry run) was given special attention in recording, while only a few other runs were completely sampled. Drain flow results for the wet runs are shown in Table 29.13 and the peak drain flows listed in Table 29.14. 
Table 29.13 Experiment 4: Summary of peak flow during dry runs.

\begin{tabular}{lrr}
\hline Run & $\begin{array}{c}\text { Total TSS } \\
\mathrm{g} / \mathrm{m}^{2}\end{array}$ & $\begin{array}{c}\text { Drain flow } \\
\mathrm{mm} / \mathrm{h}\end{array}$ \\
\hline R3 & 0 & 156 \\
R8 & 75 & 108 \\
R61 & 1,375 & 66 \\
R80 & 1,875 & 66 \\
R131 & 3,175 & 35 \\
\hline
\end{tabular}

Table 29.14 Summary of peak drain flows during wet runs.

\begin{tabular}{lll}
\hline Run & \multicolumn{1}{c}{$\begin{array}{c}\text { Total TSS } \\
\mathrm{g} / \mathrm{m}^{2}\end{array}$} & \multicolumn{1}{c}{$\begin{array}{c}\text { Peak flow } \\
\mathrm{mm} / \mathrm{h}\end{array}$} \\
\hline R2 & 0 & 180 \\
R48 & 1,050 & 139 \\
R63 & 1,425 & 97 \\
R123 & 2,950 & 45 \\
R133 & 3,225 & 37 \\
\hline
\end{tabular}

In this experiment, having a TSS application rate only $25 \%$ of the TSS application rate in experiment 3 , peak drain flow was reduced at a much smaller total TSS application. At run 131 with a total $3175 \mathrm{~g} / \mathrm{m}^{2}$ of TSS applied a minimum drain flow of $35 \mathrm{~mm} \cdot \mathrm{h}^{-1}$ was reached. This may suggest that infiltration and thus effectively, TSS trapping in the fill aggregate, is affected by the reduced rain rate.

\subsection{Results}

The following points are drawn from the results obtained in the four experiments.

The drainage cell fill material is capable of maintaining high infiltration rates for a long period of time. For experiments 3 and 4, the rainfall intensity was higher than the 5-min 100-y return period design rain for Guelph. At the end of experiments 3 and 4 the permeable pavers were still able to infiltrate at the rate of $171 \mathrm{~mm} \cdot \mathrm{h}^{-1}$ and $114 \mathrm{~mm} \cdot \mathrm{h}^{-1}$ respectively, which can accommodate a rainfall of a 5-y return period. 
In experiment 1 , at run 32 (total $3200 \mathrm{~g} / \mathrm{m}^{2}$ TSS application) peak drain flow was reduced to $20 \mathrm{~mm} \cdot \mathrm{h}^{-1}$. In experiment 2 at run 22 (total $2200 \mathrm{~g} / \mathrm{m}^{2} \mathrm{TSS}$ application) peak drain flow reduced to $19 \mathrm{~mm} \cdot \mathrm{h}^{-1}$. In experiment 3 at run 62 (total $4800 \mathrm{~g} / \mathrm{m}^{2}$ TSS application) peak drain flow reduced to $35 \mathrm{~mm} \cdot \mathrm{h}^{-1}$. In experiment 4 run 133 (total $3225 \mathrm{~g} / \mathrm{m}^{2}$ TSS application) peak drain flow reduced to $35 \mathrm{~mm} \cdot \mathrm{h}^{-1}$.

Experiment 2 showed very low drain flows at the start of the experiment and reached a peak drain flow of $35 \mathrm{~mm} . \mathrm{h}^{-1}$ during run 9 with a TSS application of $1100 \mathrm{~g} / \mathrm{m}^{2}$. This could be due to some experimental errors. For example during filling of drainage cells, an excess quantity of HPB and Sand mix was placed on the paver surface and when the blocks were compacted with a rubber hammer for firmness, more fines were transported down through the pores of the coarse HPB and compacted within the cells. It was observed, after compaction, that the excess fill aggregate removed from the paver surface was mostly coarse HPB aggregates rather than sand. This might have caused the variance in experiment 2 .

Observed surface runoff for all 4 experiments is compiled in Table 29.15. Runoff was high in experiments 1 and 2 due to the additional water flowing from the sides of the rig walls and which was corrected in experiments 3 and 4 . Excess runoff during experiment 2 was also due to the packing of drainage cells with more fines as discussed above.

The top $10 \mathrm{~mm}$ of the drainage cell fill material trapped most of the fines from the TSS applied during all experiments. HPB-base aggregate did not accumulate any fines but allowed fines to pass through and accumulate on the drain filter fabric.

Particle size analyses for experiments 1,2 and 3 suggest that most of the TSS was trapped in the top $10 \mathrm{~mm}$ of the fill aggregates although some fines also accumulated in lower layers. In the top $5 \mathrm{~mm}$ fines smaller than $0.42 \mathrm{~mm}$ increased in experiment 1 , from $0.6 \%$ to $42 \%$; during experiment 2 , from 13 $\%$ to $54 \%$; and during experiment 3 , from $9 \%$ to $44 \%$. Similarly particle sizes less than $2 \mathrm{~mm}$ increased from $8 \%$ to $76 \%$ in experiment 1 , from $42 \%$ to $85 \%$ in experiment 2 , and from $30 \%$ to $85 \%$ in experiment 3 . Furthermore, no trapping of TSS was observed in the HPB base aggregate used in experiments 1 and 2.

Results from experiment 4 suggest that clogging of drainage cells may also be related to the total number of rains and/ or total depth of rainfall rather than the total build-up of TSS alone. This may need further investigation. Experiment 4 was different from experiment 3 in two respects: (i) the TSS application rate was reduced and (ii) more coarse aggregates were used in the fill aggregate. In 
both experiments, base infiltration was $156 \mathrm{~mm} \cdot \mathrm{h}^{-1}$ but in experiment 4 at run 61 (with total TSS of $1375 \mathrm{~g} / \mathrm{m}^{2}$ ) the same peak drain flow was observed as that for experiment 3 at run 51 (with total TSS of $3800 \mathrm{~g} / \mathrm{m}^{2}$ ). This trend was opposed to what may have been expected (because of the coarse aggregate used in experiment 4). Rainfall seems to have enhanced the clogging of the drainage cells.

It was observed that the initial condition of a run has a significant influence on drain flow and surface runoff hydrographs, and for this reason the first run of the day was considered to be more reliable, for comparison purposes. This reduces the number of reliable observations. For future studies it is important to allow a fixed and sufficient time interval between two runs of each experiment.

Measuring TSS in the outflow was not cost effective, given the available research budget. To measure the transient concentration of particulates in the drainage outflow requires careful experimental procedure, instrumentation and laboratory analysis. Visually we observed that drain flows during experiment 1 and 2, were not impaired whereas the drain flows during experiment 3 and 4 were high in suspended particles for the first 25 runs. This was probably mainly due to the gradation of base material: base material in experiments 1 and 2 had less than $0.3 \%$ particles less than $0.075 \mathrm{~mm}$, while experiments 3 and 4 had $8.5 \%$ particles less than $0.075 \mathrm{~mm}$

Table 29.15 Runoff for all four experiments.

\begin{tabular}{rrrrrr}
\hline$\#$ & Run & $\begin{array}{c}\text { Accumulated TSS } \\
\mathrm{g} / \mathrm{m}^{2}\end{array}$ & $\begin{array}{r}\text { Runoff Rate } \\
\mathrm{mm}-\mathrm{h}^{-1}\end{array}$ & $\begin{array}{c}\text { Rainfall Rate } \\
\mathrm{mm}-\mathrm{h}^{-1}\end{array}$ & $\begin{array}{c}\text { Infiltration Rate } \\
\mathrm{mm}-\mathrm{h}^{-1}\end{array}$ \\
\hline 1 & 1 & 0 & 25 & 277 & 252 \\
& 48 & 4,800 & 260 & 277 & 17 \\
2 & 2 & 0 & 125 & 277 & 152 \\
& 34 & 3,400 & 210 & 277 & 67 \\
3 & 33 & 2,600 & 14 & 277 & 263 \\
& 79 & 6,400 & 106 & 277 & 171 \\
4 & 39 & 825 & 16 & 200 & 184 \\
\hline
\end{tabular}

For the purposes of this analysis, the peak base drainage rate is defined as the highest flow rate occurring in the base drainage hydrograph. Since some hydrographs exhibit several peak flows, the average peak runoff flow rate is used (the average of the highest flow rates found on each runoff hydrograph). Figure 29.6 illustrates the change occurring in the peak drainage rate and average peak runoff rate over the full course of the experiment (all 48 experimental runs). 


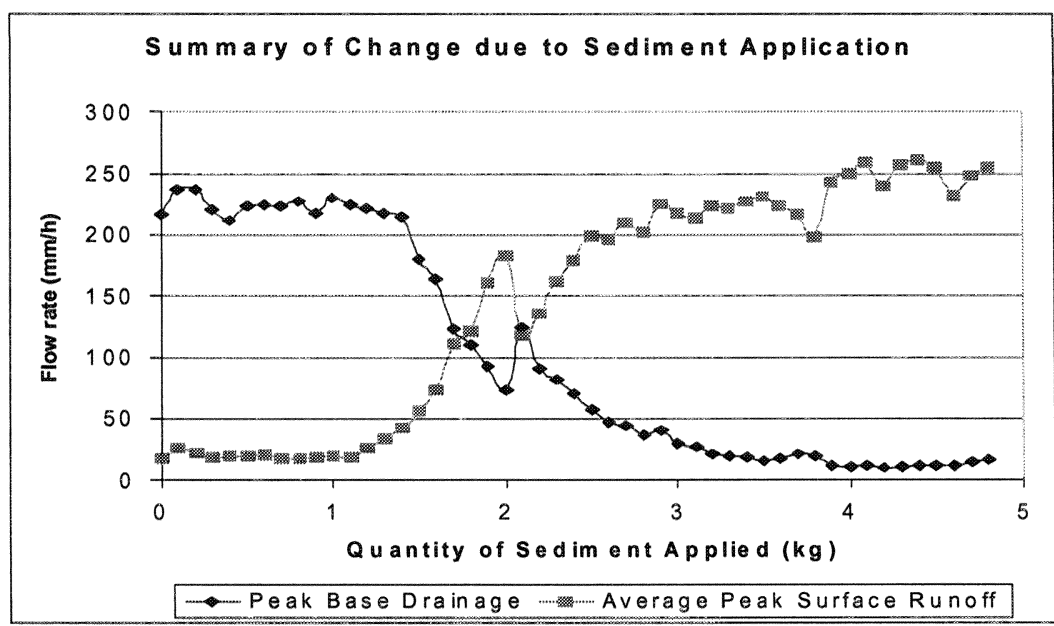

Figure 29.6 Summary of the change in the peak base drainage and surface runoff due to sediment application for experiment 2 .

During the first 14 experimental runs the peak base drainage velocity is relatively high $(230 \mathrm{~mm} / \mathrm{h})$ and is not affected by the addition of sediment. When $1.4 \mathrm{~kg} / \mathrm{m}^{2}$ of TSS has accumulated on the pavers base drainage discharge begins to decline sharply. By the addition of $2.5 \mathrm{~kg} / \mathrm{m}^{2}$ of TSS the decline in base drainage flow rates begins to lessen and by the application of $3.9 \mathrm{~kg}$ of TSS the base drainage velocity has ceased to decline. Base drainage continues at this low rate $(12 \mathrm{~mm} / \mathrm{h})$ to the end of the experiment.

Change in the flow rate of runoff follows an inverse relationship to that of base drainage. At the beginning of the experiment runoff has relatively low flows $(20 \mathrm{~mm} / \mathrm{h})$. As $1.4 \mathrm{~kg} / \mathrm{m}^{2}$ of TSS is added to the paver's surface the runoff rate begins to increase sharply. By the addition of $2.5 \mathrm{~kg}$ of TSS, the increase in the runoff begins to lessen and by the addition of $3.9 \mathrm{~kg} / \mathrm{m}^{2} \mathrm{TSS}$ the runoff has ceased to increase. Runoff continues to be produced constantly at this high rate $(250 \mathrm{~mm} / \mathrm{h})$ to the end of the experiment.

The anomalous blip that occurred in the trends of increasing runoff velocity and decreasing base drainage midway throughout the experiment was caused by a weekend delay in the results. 


\subsection{Discussion}

\subsubsection{General Trends}

Results of this experiment demonstrate that Uni-Ecostone MICBEC pavers with a high performance base of $34 \%$ porosity have the capacity to significantly reduce the volume of road runoff; viz. the high rainfall intensity $(1 / 25 \mathrm{y}$ design storm, $230 \mathrm{~mm} / \mathrm{h}$ ) selected for these experiments. Continued application of TSS to the paver surface did not immediately affect the performance of the pavers, but ultimately resulted in the failure of the infiltrating paver surface, indicating the need for maintenance.

The drainage cell fill material is capable of maintaining high infiltration rates, for a period of time, in spite of the accumulation of TSS on the paver surface. The lack of any change in the quantity of runoff produced up to the addition of $1.4 \mathrm{~kg} / \mathrm{m}^{2}$ of TSS provides a good indication of the point at which filling of the pores begins to affect the hydraulic conductivity of this drainage cell fill material. At this point the performance of the pavers begins to decline quickly. By the addition of $3.9 \mathrm{~kg} / \mathrm{m}^{2}$ of TSS a maximum runoff rate indicates the drainage cell surface pores are as full as possible using this experimental procedure.

\subsubsection{Sources of Error}

Although both the runoff and base drainage curves in Figure 29.6 are relatively smooth there is some scatter throughout the data. Much of this general scatter may be attributed to the problems with placing and removing sample bottles under the stream of base drainage or runoff water with good timing. Other possible sources of error that may explain the scatter include inconsistencies in pump or nozzle pressure, slight differences in the shut-off time of simulated rain, and variation in the rainfall characteristics due to wind or unintentional movement of the rainfall simulator position. However, since the general trends are very consistent throughout the experiment these sources of error, for the purposes of data interpretation, can be ignored.

A check for continuity was performed for each experimental run to ensure that the combined peak base drainage and peak surface runoff rate did not exceed the rainfall range $(230-270 \mathrm{~mm} / \mathrm{h})$. The results showed that continuity is observed in every experimental run.

One suspected source of systematic error arises from the variable volume of air displaced by the infiltrating water. Mixed fluid flow (water down and air 
up and then down) is likely to be time-dependent, and affected by the amount of drying time between rains. In these experiments the drying time was kept as short as possible to expedite the experiments.

\subsection{Conclusions}

Change in the performance (infiltration rates) of the permeable pavers as a result of the sediment application did not begin immediately. The quantities of sediment that can be applied without causing a decline in performance of the pavers is evidently determined by the porosity of the drainage cell fill material.

After the application of $1.4 \mathrm{~kg} / \mathrm{m}^{2}$ of TSS, the average infiltration rate at the paver surface may decline to a rate below the inflow rates (using a 1/25-y design storm of 5 -min duration with an intensity of $230 \mathrm{~mm} / \mathrm{h}$ ). More frequently observed rainfall events with lower rainfall intensities might produce different results.

After the accumulation of $3.9 \mathrm{~kg} / \mathrm{m}^{2}$ of TSS, the drainage cell material may become functionally clogged. However, over a large section of permeable pavers, heterogeneity of the infiltration rates over different sections may uphold the performance of the pavers for some time.

MICBEC permeable pavers should be maintained when the surface is affected by partial clogging. This should correspond to the accumulation of between 1.4 to $3.9 \mathrm{~kg} / \mathrm{m}^{2}$ TSS.

The results of this experiment should be compared to similar experiments using different drainage cell and base materials of varying porosity, and using different rainfall intensities and durations. In future experiments, TSS remaining on the surface should be carefully measured, to formulate a TSS balance, and help determine its path and fate .

\section{Acknowledgments}

Experiment 1 was conducted and compiled by Wilson (2002), but the particle size analyses of (i) cell fill aggregate with its in-washed TSS and (ii) base aggregate with its trapped TSS, for experiment 1, were conducted by ul Haq (2002), as were the other experiments. 


\section{References}

Balades, J-D, M. Legret and H. Madiec. 1995. Permeable pavers: Pollution Management Tools. Wat. Sci. Tech. 32(1):49-56.

Cedergren, H.R., Arman, J.A. and O'Brien, K.H. 1973. Development of Guidelines for the Design of Subsurface Drainage Systems for Highway pavers Structural Sections. Guidelines for Design, FHWA-RD-73-14. Washington, D.C.: Federal Highway Administration.

Ellis, J.B. and Marsalek, J. 1996. Overview of Urban Drainage: Environmental Impacts and Concerns, Means of Mitigation and Implementation Policies. J. of Hydraulic Research. 34 (6): 723-731.

Environment Canada, Atmospheric Environment Service. 2002. Intensity-Duration Frequency Data for Toronto, Ontario. Environment Canada's Green Lane Website (http://weatheroffice.ec.gc.ca/canada_e.html) Accessed July 17th, 2002.

Environmental Protection Agency (EPA). 1992. Plastic Pellets in the Aquatic Environment Sources and Recommendations, Final Report EPA 842-B-92-010

Environmental Protection Agency (EPA). 2002. Stormwater Technology Fact Sheet 1999. Report Number: EPA 832-F-99-023 Environmental Protection Agency website (http://www.epa.gov/npdes/pubs/porouspa.pdf .). Accessed July 15th, 2002.

Evans, M.D. 1989. Concrete Block Paving and its Effectiveness Around Street Trees. MLA Thesis. Cornell University. January 1989.

Goforth, G.F., E.V. Diniz and J.B. Rauhut. 1983. Stormwater Hydrological Characteristics of Permeable and Conventional Paving Systems. Prepared for the Municipal Environmental Laboratory, Office of Research and Development of the USEPA, Cincinnati OH, EPA-600/2-83-06.

Hossain, M. and L.A. Scofield. 1991. Permeable Paving for Control of Highway Runoff: Final Report. Prepared for the Arizona Department of Transportation and the Federal Highway Administration. Report No. FHWA-AZ91-352.

Isenring, T., H. Koster and I. Scazziga. 1990. Experiences with Permeable Asphalt in Switzerland. Transportation Research Record. 1265: 41-53.

James, W., Huber, W.C., Pitt, R.E., Dickinson, R.E., Roesner, L.A., Aldrich, J.A. and James, W.R.C. 2002. Users guide to the USEPA Stormwater Management Model and to PCSWMM. CHI pubs. Guelph (R219). ISBN 0-9683681-8-2. ca 650 pp.

Kresin, C., W. James and D. Elrick. 1996. "Observations of Infiltration Through Clogged Porous Concrete Block Pavers." Journal of Water Management Modeling R195-10. doi: 10.14796/JWMM.R195-10.

Lawrence, A.I., Marsalek, Ellis, J.B. and Urbonas, B. 1996. Stormwater Detention and BMP's. Journal of Hydraulic Research. 34 (6): 799-813.

Lefebvre, G. 1993. Permanent International Association of Road Congress, Technical Committee on Flexible Roads, Technical Committee on Surface Characteristics, 
Belgium $161 \mathrm{pp}$.

Mikkelsen, P.S., Jacobsen, P. and Fujita, S. 1996. Infiltration Practice for Control of Urban Stormwater. Journal of Hydraulic Research. 34 (6): 827-840.

Pratt, C.J. 1995. A Review of Source Control of Urban Stormwater Runoff. Journal of the Chartered Institution of Water and Environmental Management. 9 (2): 132139

Pratt, C.J., J.D. Mantle and P.A. Schofield. 1995. UK Research into the Performance of Permeable pavers, Reservoir Structures in Controlling Stormwater Discharge Quantity and Quality. Wat. Sci. Tech. 32(1):63-69.

Schueler, T. 1987. Controlling Urban Runoff: A practical manual for planning and designing urban BMPs. Metropolitan Washington Council of Governments, Washington, DC.

Schueler, T. and Brown, W. 1997. National pollutant removal performance database for stormwater best management practices, Center for Watershed Protection

St. John, M and Horner, R. 1997b. Permeable Asphalt Road Shoulders: Effect of Road Sanding Operations and Their Projected Life Span. In: The Washington Water Resource; The quarterly report of the Center for Urban Water Resources Management. 8(4).

St. John, M.S. and R.R. Horner. 1997a. Effect of Road Shoulder Treatments on Highway Runoff Quality and Quantity. WA-RD-429.1. Washington State Dept of Transportation, Olympia, WA.

ul Haq, Rizwan. September 2002. Ecostone Porous Pavement Clogging Research Experiments. CHI Research report.

Uni-Group U.S.A. 2001. UNI Eco-Stone(r) Product Information. Website (http:// www.uni-groupusa.org/informat.htm). Accessed July 24th, 2002.

Watershed Management Institute (WMI). 1997. Operation, Maintenance and Management of Stormwater Management Systems. Prepared for U.S. EPA, Office of Water, Washington, DC.

Wilson, Matthew. 2002. The rate of clogging of concrete pavers, MEng Project report, University of Guelph

Young, G. Kenneth, Stuart Stein, Pamela Cole, Traci Kammer, Frank Graziano, Fred Bank. 1996. Evaluation and Management of Highway Runoff Water Quality. Office of Environment and Planning, Federal Highway Administration, Washington, D.C. 